のメスの尿に特異的なバイオマーカーを探すことによっ てフェロモン候補物質を見つけてアッセイし, 最終的に フェロモン分子の解明を目指すのである. フェロモンが 複数成分からなる場合にこの方法は特に有効である.こ れを実行するためには, 最低でも脱皮前, 脱皮後のオス とメスの尿 4 種類を採集して, それらの成分の比較をす る必要がある。また，すべての個体は同じ水に入ってい て, 浸透圧その他の尿の成分に影響を与える飼育条件が 同じである必要もある.

この成分比較実験は他のカ二類では脱皮前後の雌雄両 個体を同時に大量に手に入れることが難しいので実行で きなかったが，ブルークラブでは以下に記すソフトシェ ルクラブ（殼の軟らかいカニ）産業の存在により可能と なった. 成熟脱皮直前のブルークラブはソフトシェルク ラブ専門の水産業者に集められ, 飼育下で脱皮させられ て，殼が軟らかいうちにソフトシェルクラブという名の 高級食材として市場に送られる。ソフトシェルクラブを 生産する水産業者はオス, メスの脱皮前の個体を大量に 1 つの水循環システムの中で飼育しているので, 飼育水 の浸透圧を一定にした脱皮前後のオス, メスの尿の比較 が可能である. 実際に，これら各脱皮段階の尿を集め， オスーメス間の尿の ${ }^{1} \mathrm{H}-\mathrm{NMR}$ を測定し比較したところ, 脱皮前のオスーメス間で大きな差が見られた. 現在, 他の 機器分析法, LC-MS, 2 次元 NMR などを用いて尿の比
較分析をしてやはりオスーメス間の違いを見いだしてい る。これらの手法を用いて見いだした化合物を効率化し たバイオアッセイ法で試験していけば，ブルークラブの 性フェロモン分子の解明につながる可能性は高い.

現在，ブルークラブを漁獲する漁師は成熟した生きた オスガニを誘引剤として用いて脱皮前のメスガニを捕獲 しており，フェロモンによる種，および性選択的な漁獲 が可能であることを示しているが，フェロモンを放出す るオスのカ二を見つけるのに苦労している. 雌雄のフェ ロモンを同定して安定供給できるようになれば，ブルー クラブの成熟したメス，また逆にオスのみを捕獲する選 択的な漁法の実現も夢ではない，そうすれば，混獲を防 いだ理想的な漁獲管理が行なえ，持続可能な海洋生物資 源利用のための技術開発へとつながることも期待され る.

1) V.S. Kennedy \& L.E. Cronin (ed.): "The Blue Crab Callinectes sapidus", Maryland Sea Grant College, College Park, 2007.

2) R. A. Gleeson : in "Crustacean Sexual Biology", ed. by R. T. Bauer and J. W. Martin, Columbia University Press, New York, 1991, p. 17.

3) M. Kamio, M. A. Reidenbach \& C. D. Derby:J. Exp. Biol., 211, 1243 (2008).

4) M. Kamio : Ann. N.Y. Acad. Sci., 1170, 456 (2009).

（神尾道也, 東京海洋大学海洋学部)

\title{
界面活性剈様ペプチドの自己組織化 両親媒性ペプチドの特性を利用して様々な性質を自在につくり出す
}

家庭用洗剂として広く知られている「界面活性剂」は, 1 つの分子内に親水基と疎水基 (親油基) を有する両親 媒性化合物である. 市販されているものだけでも数百種 類存在し, 現在の生活様式を支える上で不可欠なものと なっている. 生物学の世界（だけではないが）でもミセ ルやベシクル， 細胞膜という形で恩恵を受けている.

界面活性剤といえば, 教科書的には「親水性官能基と 長鎖アルキル基」という構造が多く描かれており, 市販 界面活性剤もこうした骨格が大多数を占めている. とこ ろが，もう 1 つのキーワードである両親媒性化合物とい う観点に立つ之, タンパク質の立体構造形成モチーフの 1 つとして知られている構造体になる。両親媒性ペプチ ドを「界面活性剤様ペプチド」と見立てた場合,「界面活
性剂屋さんにペプチドの活用を，ペプチド屋さんに界面 活性剤としての利用を」という目線を提供できるのでは という立場から界面活性剂様ペプチドの自己組織化につ いて紹介する.

Lac リプレッサータンパク質の C 末端領域は両親媒 性 $\alpha$-ヘリカルコイルドコイル構造を形成する ${ }^{(1)}$. Middelberg のグループは，この部位を基本配列とした Lac

表 1 - Lac リプレッサーの C 末端領域に由来するペプチドの アミノ酸配列

Lac(339-) PRALADSLMQLARQVSRLESGQ

Lac21 Ac-MKQLADSLMQLARQVSRLESA-CONH

AM1 Ac-MKQLADSLHQLARQVSRLEHA-CONH

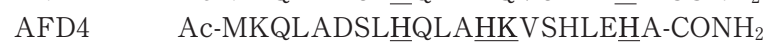


21 ペプチドを用いて peptide surfactant (Pepfactant: 表 1) を設計した ${ }^{(2)}$. Lac21 は両親媒性モチーフを有しな がらも安定に泡を維持することができなかった．Lac21 にHisを 2 残基導入したAM 1 は Lac 21 と同様な挙動 を示したが, $\mathrm{Zn}^{2+}$ や $\mathrm{Ni}^{2+}$ 存在下で錯体形成すること によって分子間会合が可能となり, 安定な泡を形成する ことができた. His をさらに増やした AFD4 も遷移金属 イオン存在下で安定な泡を形成し，その泡立ち度合いは $\mathrm{AM} 1$ よりも優れていた ${ }^{(3)}$.これらの泡立ち現象は EDTA の添加や $\mathrm{pH}$ を下げることによって容易に消失 した. AM1 や AFD4 の発泡消泡性は可逆的な応答を示 したことから, 両親媒性構造によって発泡が可能にな り, 分子間会合力の度合いが泡の安定化に寄与している ことがわかる。

界面活性剂の基本構造である「長鎖アルキル基+親水 性官能基」に類似した構造のペプチドをシンプルに設計 するには，疎水性側鎖を有するアミノ酸と側鎖に電荷を もつアミノ酸を組み合わせることになる. Zhang のグ ループは Ac-Xaa $-\mathrm{Asp}_{n}-\mathrm{OH}(\mathrm{Xaa}=\mathrm{Leu}, \mathrm{Val}, \mathrm{Ala} ; n=$ 1〜2) を設計合成し, その構造を観察した ${ }^{(4)}$. 透過型電子 顕微鏡により直径 30〜 $50 \mathrm{~nm}$ の筒状構造体が観測され, 2 分子膜構造によるナノチューブを形成していることが 示された. また疎水性部分として Leuなどの代わりに Gly を用いた Ac-Gly $6-\mathrm{Asp}_{2}-\mathrm{OH}$ も同様な構造体形成が 見られた ${ }^{(5)}$.これらのことから, 疎水領域に炭化水素鎖 側鎖を有するアミノ酸残基は必須ではなく, 親水一踈水 バランスに基づいたアミノ酸配列設計を行なうことで界 面活性剤様ペプチドになることが示されている.
界面活性剤の基本構造に立ち返ったとき，界面活性剤 様ペプチド分子の構造は親水性ペプチドに炭化水素鎖を 付与したものあるいは疎水性ペプチドに親水性官能基を もたせたものになる，そのような化合物は水溶液中で長 鎖アルキル基の疎水的凝集によりペプチド部分の近接を もたらす。立体構造形成時に分子間会合を必要とするぺ プチドに長鎖アルキル基修飾を行なえば，疎水基の集合 に基づいたペプチド部分の会合が誘起できると期待でき る. 逆にペプチド部分の会合力が強いと, 炭化水素鎖の 会合濃度を下げると考えられる。こうした観点から筆者 らは，コラーゲンモデルペプチドを親水基に用いて，そ のアミノ末端にラウリン酸を共有結合した長鎖脂肪酸型 界面活性剂様化合物, Lau-(Pro-Hyp-Gly) ${ }_{3}-\mathrm{OH}$ を設計合 成した(6). コラーゲンは (Xaa-Yaa-Gly) ${ }_{n}$ の配列をもち, ペプチド鎖 3 本がより合わさった 3 重鎖構造を形成する が，ペプチド鎖が短い $(n<4)$ と 3 重鎖構造を形成でき ない,ところが, Lau-(Pro-Hyp-Gly) 小 $_{3}-\mathrm{OH}$ からは水溶液 中 $1 \mathrm{~mm}$ の濃度でコラーゲン様 3 重鎖構造を示す 225 $\mathrm{nm}$ 付近に正の極大をもつ CD スペクトルパターンが得 られた。 また， CD 強度の濃度依存性を調べると $250 \mu \mathrm{M}$ 付近に屈曲点を示す形で濃度増大とともに強度の増加が 見られた，濃度の増大に伴って水中における長鎖アルキ ル基の会合が始まり，ペプチド鎖部分の近接が誘起され ることで短鎖ペプチドであってもコラーゲン様 3 重らせ ん形成が可能になったと考えられる（図 1).

ペプチド分子内に明瞭な親水一疎水領域をもたせたり, 親水性ペプチドを単純に炭化水素鎖で修飾することによ り界面活性剂様ペプチドをつくることができ，それぞれ

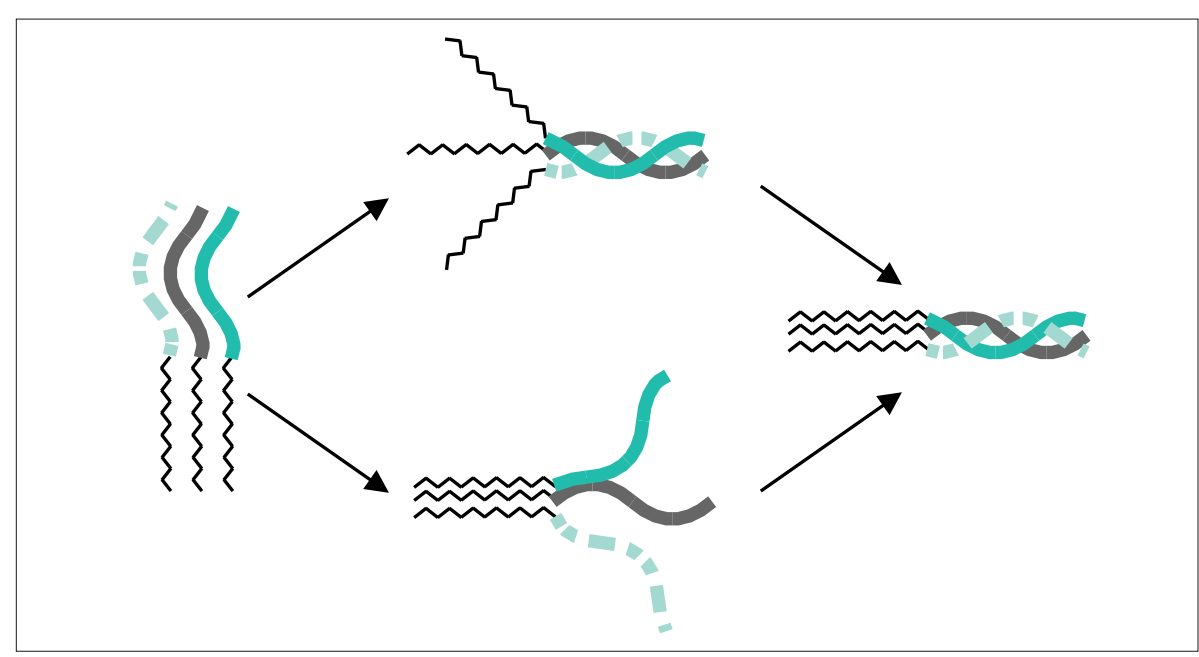

図 1 ・脂質修飾型コラーゲンモデ ルペプチドの会合過程の模式図 ペプチド部分の会合力と炭化水素鎖 の会合力の強さの違いにより，2つ の過程が考えられる. 
の分子構造に特異的な様式で自己組織化が進む例を示し た。界面活性剤は生活に不可欠なものでありながら環境 中で持続的に存在し続けるものが多い. 環境問題や生体 親和性なども考えていく上で，「ペプチドによる界面活 性剂」の分野が開けていくことを願う.

1) A. E. Chakerian, V. M. Tesmer, S. P. Manly, J. K. Brackett, M. J. Lynch, J. T. Hoh \& K. S. Matthews: J. Biol. Chem., 266, 1371 (1991).

2) A. S. Malcolm, A. F. Dexter \& A. P. J. Middelbreg : Asia-
Pac. J. Chem. Eng., 2, 362 (2007).

3) A. F. Dexter \& A. P. J. Middelberg:J. Phys. Chem. C, 111, 10484 (2007).

4) S. Vauthey, S. Santoso, H. Gong, N. Watson \& S. Zhang: Proc. Natl. Acad. Sci. USA, 99, 5355 (2002).

5) S. Santoso, W. Hwang, H. Hartman \& S. Zhang : Nano Lett., 2, 687 (2002).

6) Y. Tanaka, Y. Sugiyama, M. Naito, J. Kuwahara, N. Nishino, K. Kaibara \& H. Akisada: Peptide Sci., 2008, 459 (2009).

(田中雄二, 九州共立大学共通教育センター)

\section{乳酸菌のヒスタミン生成遺伝子は種を超えて転移する? ヒスタミン生成遺伝子の伝播機構に挑む}

ヒスタミンは生体内の生理活性アミンとして有名であ るが, 食品衛生の分野ではアレルギー様食中毒の原因物 質としてしばしば問題となる．食品中のヒスタミンはア ミノ酸であるヒスチジンが微生物により脱炭酸されて生 じる. 無色, 無臭で一般的な加熱調理では分解されず, 大量に接種すると，じんましんなどの症状が現われる. サバやマグロなど，ヒスチジンを大量に含む赤身魚は原 因食品となることが多い(1)（文献 1 には規制值について の現状も記述あり). 近年, 食の安全安心志向の高まり, 加工残滓の有効利用などの観点から, 魚介類を原料とし た天然発酵調味料 (魚奨油) の製造量が激増している.

一般的な魚奨油は原料魚に終濃度 $20 \%$ 程度の食塩を加 え 1 年以上発酵させたもので, 敖などを使用する製法も 知られている. しかし, 発酵調味料製造過程において, ヒスタミンが蓄積することがあり, 製品によっては 2,000 ppm を超えることもある. 上記のように魚奨油は 高塩分で pH 5.0 前後と低く, 微生物による作用は起こ り難いと考えられるが, 好塩性ヒスタミン生成乳酸菌の 存在が過去に報告されている(2). このことから，筆者ら は魚奨油発酵過程でヒスタミンを生成する菌群を分離 し, ヒスタミン生成に関与する遺伝子について解析して いる(3). 今回は，これまであまり知見のなかった好塩性 乳酸菌のヒスタミン生成遺伝子について紹介する.

ヒスタミン生成菌はニギス (Glossanodon semifasciatus ; 深海 $(200 \mathrm{~m})$ に住むキスに似た魚. キスとは異な る）を原料として䡘を用いて発酵させた市販魚滰油から 分離した. 魚奨油発酵中の化学成分をモニタリングした 結果, 仕込み直後の試料ではヒスタミンの蓄積が見られ ず，発酵中にヒスタミン量が急増していた。 食塩濃度
$20 \%$ のモロミ中で発酵開始後 1 力月程度経ってからヒ スタミン量が増加しているため, 増殖した好塩性細菌が ヒスタミンを生成していると考えられた。 そこで，通常 のヒスタミン生成菌分離培地に食塩を加えて, 好塩性七 スタミン生成菌の分離を試みたところ, 全生菌数に対し て $0.01 \%$ 以下の占有率であったが，ヒスタミンを生成す る菌を分離することができた. 分離菌は形態, 生化学性 状および遺伝子の塩基配列の解析により好塩性乳酸菌で ある Tetragenococcus halophilus と同定された。

本菌は, 増殖に高濃度の食塩を必要とし（至適食塩濃 度 7〜10\%), 大豆滰油や味噌から常在菌として分離され る(4). 魚滰油からも優占菌として分離されるが，ほとん どの株はヒスタミンを生成しない. 分離菌のヒスタミン 生成酵素（ヒスチジンデカルボキシラーゼ；HDC）を コードしている遺伝子の塩基配列を解析したところ, ワ インやチーズなどから分離されたLactobacillus 属や Oenococcus 属細菌がもっていたピルボイル型 HDC 遺 伝子 $(h d c A)$ と高い相同性を示した. ピルボイル型 $\mathrm{HDC}$ は分子量約 $200 \mathrm{kDa}, \alpha, \beta$ サブユニットで構成さ れるヘテロ六量体で, ピルボイル基（ピルビン酸から誘 導される 1 価のアシル基 $\mathrm{CH}_{3} \mathrm{COCO}-$ ）をむつのが特徴 である ${ }^{(5)}$. 乳酸菌の場合, ヒスタミン生成に関与する遺 伝子群は構造遺伝子である $h d c A$ を含む 4 つの遺伝子 $(h d c P, h d c A, h d c B, h d c R S)$ で構成されている.

現在データベースに登録されている $h d c A$ の塩基配 列を集めて系統樹を作成したのが図 1 で，魚奨油由来株 が属するクラスター内で非常に高い相同性を示している のがよくわかる.このクラスターに入っている菌種はす ベて乳酸菌であるが, 属レベルで多様性があり, $16 \mathrm{~S}$ 